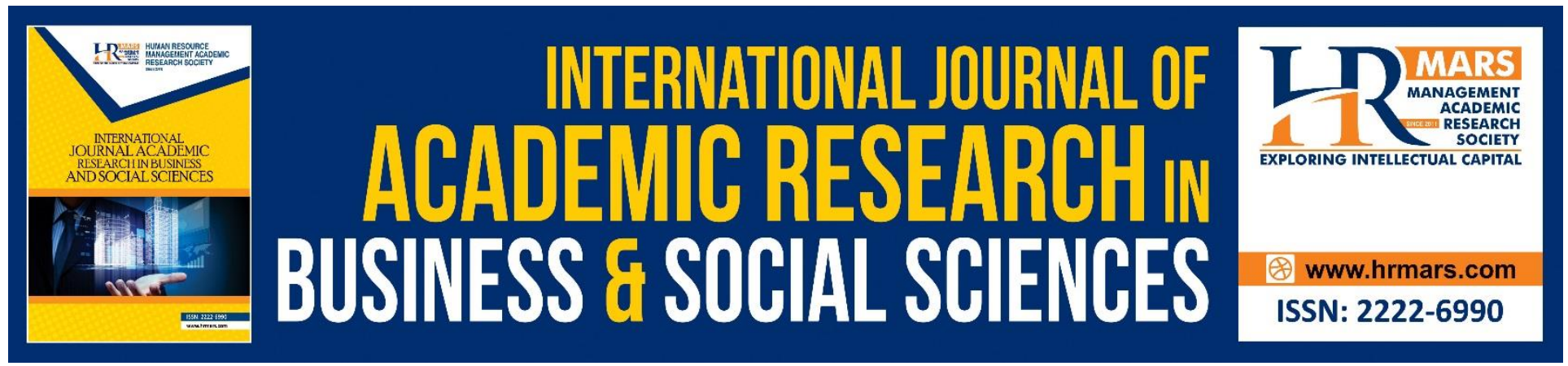

\title{
Assessment of Effectiveness My Kampung My Future Program Based on CIPP Model: Process Dimension
}

\section{Fatin Nur Aqmar Ishak \& Ridzwan Che' Rus}

To Link this Article: http://dx.doi.org/10.6007/IJARBSS/v8-i10/5827

DOI: $10.6007 /$ IJARBSS/v8-i10/5827

Received: 10 Sept 2018, Revised: 28 Sept 2018, Accepted: 1 October 2018

Published Online: 29 October 2018

In-Text Citation: (Ishak \& Rus, 2018)

To Cite this Article: Ishak, F. N. A., \& Rus, R. C. (2018). Assessment of Effectiveness My Kampung My Future Program Based on CIPP Model: Process Dimension. International Journal of Academic Research Business and Social Sciences, 8(10), 1586-1592.

\section{Copyright: (C) 2018 The Author(s)}

Published by Human Resource Management Academic Research Society (www.hrmars.com)

This article is published under the Creative Commons Attribution (CC BY 4.0) license. Anyone may reproduce, distribute, translate and create derivative works of this article (for both commercial and non-commercial purposes), subject to full attribution to the original publication and authors. The full terms of this license may be seen

at: http://creativecommons.org/licences/by/4.0/legalcode

Vol. 8, No. 10, 2018, Pg. 1586 - 1592

http://hrmars.com/index.php/pages/detail/IJARBSS

JOURNAL HOMEPAGE

Full Terms \& Conditions of access and use can be found at http://hrmars.com/index.php/pages/detail/publication-ethics 


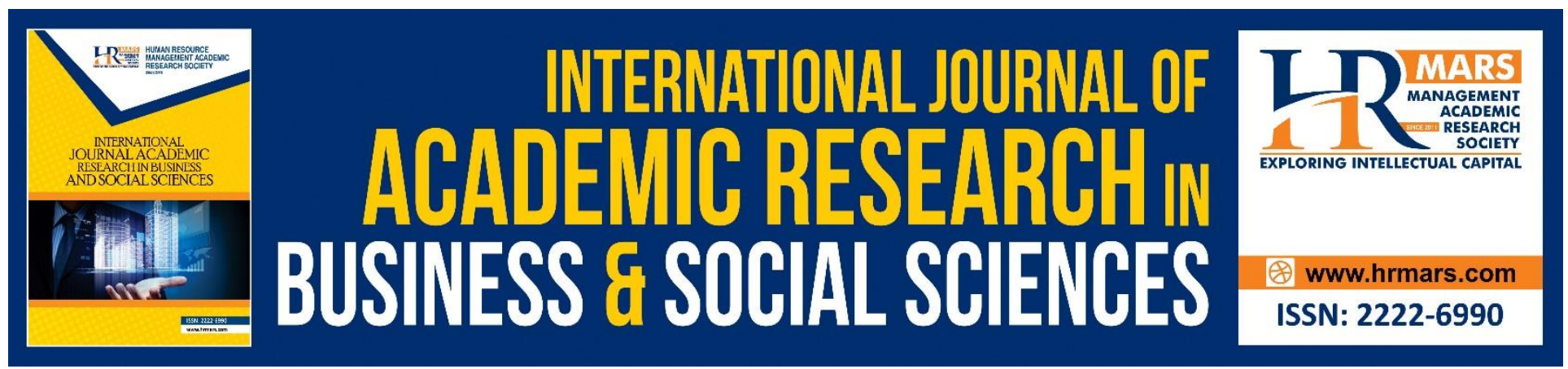

\title{
Assessment of Effectiveness My Kampung My Future Program Based on CIPP Model: Process Dimension
}

\author{
Fatin Nur Aqmar Ishak \& Ridzwan Che' Rus \\ Faculty of Technical and Vocational, Universiti Pendidikan Sultan Idris \\ Perak, Malaysia
}

\begin{abstract}
The purpose of this study is to evaluate the effectiveness of the My Kampung My Future (MKMF) program based on the process dimensions in the CIPP assessment model. The CIPP assessment model was selected as it emphasized the continuous improvement process of a program that has yet to or has been conducted. Thus, the process dimensions in this study focused more on the implementation strategy in the MKMF program. Questionnaires were distributed to 212 MKMF participants and then the data were analysed using SPSS software. The findings showed that the total mean value was at high level. However, there were two moderate constructs in terms of problem solving and loss liability. It was clearly shown that the assessment process is crucial in the pursuit of continuous improvement to ensure the sustainability of the program in the future.

Keywords: Assessment, My Kampung My Future Program, CIPP Assessment Model, Improvement, Agricultural Sector
\end{abstract}

\section{Introduction}

Basically, until now the agricultural sector still contributes to the country's economic development. Nevertheless, the contribution of the agriculture sector to Gross Domestic Product (GDP) has declined since the 70's to the year 2013. The agricultural sector is often associated with the production of raw commodities and primary marketing activities. Today, the function of the agricultural sector is seen in overall economic aspect which shows the real function of the agricultural sector to drive the country's economy (Othman and Jafari, 2014).

However, developed countries such as Japan, Netherlands and United States have recognised the agricultural sector with other sectors. In fact, the agricultural sector is also able to provide job opportunities and provide a great return if it is well-run and systematic. Modern farmers are also capable of becoming a millionaire and producing their own high quality products (Abidin, Anuar and Abdullah, 2015). In addition, the agricultural sector has actually managed to achieve high standard as a major contributor to the country's economy. Likewise, with the livestock sector, fisheries sector, food industry and SMI (Small and Medium Industry) due to the existence of various uniqueness as well as providing valuable benefits to present and future generations as a major source of income. 
The development of agricultural sector is based on the National Agro-Food Policy (2011-2020), Food Supply Guarantee Policy (2008) and National Commodity Policy (2011-2020) which aimed to increase food and export of industrial commodities (11th Malaysia Plan 2016-2020). Thus, food production is very important in ensuring the sustainability of future generations. Furthermore, lack of supply of food sources can cause various negative symptoms such as infectious diseases, malnutrition and mortality. In this context, global food supply is increasing and secured when youth participation in the agriculture sector is also increasing.

According to a report of the 10th Malaysia Plan (RMK-10) launched in 2011 (2011-2015), the government showed efforts taken to empower the agricultural sector that could generate national income to produce agricultural entrepreneurs among highly educated youths. In addition, it is also able to change the perception of the youth towards the agricultural sector. The actual agricultural sector covers a very broad aspect as it is also closely related to the field of business as well as entrepreneurship and food production. It also includes the livestock sector, fisheries sector, food processing industry and SMI.

According to MOA (2012), the government has organised a program that is capable of attracting more youth interest in the agricultural sector. In fact, the livestock sector, fisheries sector, food processing industry and SME are also involved. The program is known as My Kampung My Future (MKMF) Kampungku Masa Depan Ku. The program aims to increase and encourage the involvement of youths in rural areas in economic activities that are capable of generating income and economy of the country. It also assists in identifying the strengths of each village in a particular sub-sector. It is able to improve the agro-food industry whose resources are the result of the agricultural sector itself and contributed by the livestock sector, fisheries sector, the food processing industry and SMI.

To ensure the effectiveness and success of the program, it should go through regular evaluation process. According to Stufflebeam (1973), each program that has been implemented should go through an evaluation process for continuous improvement in the pursuit of a more positive and promising impact in the future. Hence, it is able to maintain the continuity of the program.

Therefore, in order to foster the interest of the youth in the agricultural sector, a study was conducted in the effort to evaluate the effectiveness of the MKMF program implementation using the CIPP assessment model approach. According to Stufflebeam, Folely, Gephart, Guba, Hammond, Merriman and Provus (1971), the CIPP assessment model works in evaluating either before, during and after the program. It is able to fulfil the program planning and administration needs as well as improve the information used as a guide in planning a program.

\section{Program My Kampung My Future}

The MKMF program is a program organized by the MOA and other agencies beginning in 2012. The program is based on the agriculture as well as entrepreneurship sectors. It also involves the livestock sector, fisheries sector, food processing industry and SMI. The main goal of the program is to attract rural youth to venture into the agricultural sector, highlight the diversity and uniqueness of the 
INTERNATIONAL JOURNAL OF ACADEMIC RESEARCH IN BUSINESS AND SOCIAL SCIENCES Vol. 8, No. 10, Oct. 2018, E-ISSN: 2222-6990 @ 2018 HRMARS

agricultural sector to the public and ensure the adequacy of food supply sources. In addition, it lowers the percentage of unemployment problems among youths and percentage of migration of youth to the city (MOA, 2012).

\section{CIPP Assessment Model}

The CIPP assessment model was designed by Danial L. Stufflebeam in 1970. The abbreviation for the CIPP means C (Context), I (Input), P (Process), P (Product) as shown in Figure 1. Additionally, this assessment model is a result of an idea from Stufflebeam's experience in an educational assessment project at the Ohio Public Schools District. However, this assessment model emphasises on aspects of assessment and information in making decisions on a management and operating program. Nevertheless, the information in the assessment aspect is able to assist the program manager in making the right decision. Thus, the assessment process is conducted on a certain aspect without waiting for the process at another level. The main purpose of this assessment model is to help make decisions in planning a valuation that adds value to the results obtained (Guba and Stufflebeam, 1971).

Figure 1: CIPP Assessment Model Dimensions

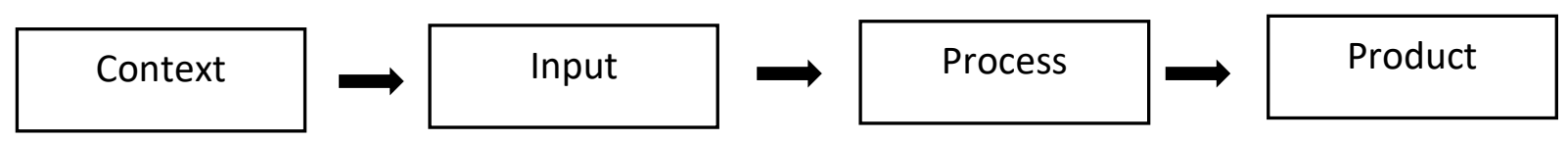

Source: Stufflebeam (1971)

According Patton (2002), the aim of this assessment model is to assess programs that are able to obtain more systematic information related to the activities, features and outcomes of the programs being conducted to be practiced specifically, able to eliminate the uncertainty and control negative decisions. Gay (1985) also supported that the aspect of assessment is a systematic process during the process of collecting and analysing data in order to ensure the achievement of an objective. Systematic judgments are usually influenced by credible information in making any decisions.

\section{Dimension Process Assessment}

The assessment process is the management of a program. In other words, researchers need to do the handling and reviewing process for each planning so that the assessment process can be carried out more effectively. The purpose of the process dimension assessment is to know the journey in a program to achieve positive and successful goals and objectives (Stufflebeam, 1970).

\section{Research Objective}

This study is conducted to assess the effectiveness of the process dimension from the implementation strategy point of view in achieving the objective of the MKMF program.

\section{Research Question}

The research question for this study is:

To what extent the process dimension from the perspective of implementation strategies in achieving the objective of the MKMF program based on the CIPP assessment model? 
INTERNATIONAL JOURNAL OF ACADEMIC RESEARCH IN BUSINESS AND SOCIAL SCIENCES

Vol. 8, No. 10, Oct. 2018, E-ISSN: 2222-6990 @ 2018 HRMARS

\section{Methodology}

The questionnaires were distributed to 212 participants of MKMF at several locations. However, the MKMF participants were briefed on the questionnaire instrument. Participants of the MKMF were given 15 minutes to answer all questions. The questionnaire instrument was verified by five experts comprising two MOA officers and three experts in the KIPP assessment model. The data obtained was analyzed using SPSS software.

\section{Research Findings}

Descriptive data were expressed in mean and standard deviation values. According to Pallant (2013), the mean value can be categorised into three main groups; 1.00 to 2.33 as low category, 2.34 to 3.66 as medium category and 3.67 to 5.00 as high category as shown in Table 1.

Table 1: Mean values category

\begin{tabular}{lc}
\hline Mean value & Description \\
\hline 1.00 to 2.33 & Low level \\
2.34 to 3.66 & Medium level \\
3.67 to 5.00 & High level \\
\hline
\end{tabular}

Source: Pallant (2013)

Furthermore, Table 2 shows that 13 items of questionnaires were used to answer the research question. As shown in the table, the mean values of Process_1 to Process_9, Process_12 and Process_13 were high level. However, only Process_10 (3.60) and Process_11 (3.55) have a medium level of mean value. Hence, the total mean value was 3.90, indicating high level of mean value, whereas the standard deviation value was 0.569 . Overall, the total mean value was at high level. 
INTERNATIONAL JOURNAL OF ACADEMIC RESEARCH IN BUSINESS AND SOCIAL SCIENCES Vol. 8, No. 10, Oct. 2018, E-ISSN: 2222-6990 @ 2018 HRMARS

Table 2: Implementation strategy to achieve objective of MKMF program based on CIPP assessment model

\begin{tabular}{|c|c|c|c|c|}
\hline No. & $\begin{array}{l}\text { Implementation strategy to } \\
\text { achieve MKMF program } \\
\text { objective }\end{array}$ & $\begin{array}{l}\text { Mean } \\
\text { value }\end{array}$ & $\begin{array}{l}\text { Standard } \\
\text { deviation }\end{array}$ & $\begin{array}{c}\text { Mean value } \\
\text { level }\end{array}$ \\
\hline Process_1 & $\begin{array}{l}\text { Explanation on implementation } \\
\text { strategy for MKMF program by } \\
\text { MOA officer }\end{array}$ & 4.01 & 0.568 & High \\
\hline Process_2 & \begin{tabular}{ll} 
Participants & \multicolumn{2}{c}{ understood } \\
implementation & strategy of \\
MKMF program &
\end{tabular} & 3.95 & 0.504 & High \\
\hline Process_3 & $\begin{array}{l}\text { Explanation on actual goal of } \\
\text { MKMF program by MOA officer }\end{array}$ & 3.97 & 0.491 & High \\
\hline Process_4 & $\begin{array}{l}\text { Participants understood actual } \\
\text { goal of } M K M F \text { program }\end{array}$ & 4.00 & 0.477 & High \\
\hline Process_5 & $\begin{array}{l}\text { Participants carried out activities } \\
\text { based on interest }\end{array}$ & 3.94 & 0.512 & High \\
\hline Process_6 & $\begin{array}{l}\text { Participants carried out activities } \\
\text { based on sutaibility of place }\end{array}$ & 4.00 & 0.487 & High \\
\hline Process_7 & $\begin{array}{l}\text { Explanation on marketing } \\
\text { concept by MOA officer }\end{array}$ & 3.95 & 0.544 & High \\
\hline Process_8 & $\begin{array}{l}\text { Participants were exposed with } \\
\text { actual marketing concept }\end{array}$ & 3.89 & 0.539 & High \\
\hline Process_9 & $\begin{array}{ll}\text { MKMF program } & \text { helped } \\
\text { participants to market } & \text { MKMF } \\
\text { products } & \end{array}$ & 3.91 & 0.573 & High \\
\hline Proses_10 & MOA helped in problem solving & 3.60 & 0.828 & Moderate \\
\hline Proses_11 & MOA incurred all losses & 3.55 & 0.810 & Moderate \\
\hline Proses_12 & $\begin{array}{l}\text { MOA provided spiritual support } \\
\text { and guidance to MKMF } \\
\text { participants }\end{array}$ & 3.92 & 0.607 & High \\
\hline Proses_13 & $\begin{array}{l}\text { MOA monitored all activities } \\
\text { that were carried out }\end{array}$ & 3.95 & 0.454 & High \\
\hline & TOTAL & 3.90 & 0.569 & High \\
\hline
\end{tabular}

\section{Conclusion}

In conclusion, the process dimensions need to present in the process of appraisal of a program. In this study, the process dimensions emphasize the implementation strategy in achieving the MKMF program objective to evaluate the implementation of the MKMF program. As a result, the total mean value was in high level. However, there were two mean values having moderate level in problem solving and loss liability. Therefore, the authorities should work together to improve the process in 
INTERNATIONAL JOURNAL OF ACADEMIC RESEARCH IN BUSINESS AND SOCIAL SCIENCES

Vol. 8, No. 10, Oct. 2018, E-ISSN: 2222-6990 ㄷ 2018 HRMARS

order to ensure the sustainability of the program in the future, thus promoting the involvement of the youth in the program. Besides that, it also promotes the agricultural sector as well as other related sectors to drive the country's economy thus ensuring the adequacy of food supply sources.

\section{References}

Economy Planning Unit. Eleventh Malaysia Plan (2016-2020). Bab 8: Engineered Economic Growth to Increase Prosperity.

Economy Planning Unit. Tenth Malaysia Plan (2011-2015). www.epu.gov.my. Uploaded on 1 October 2016.

Gay, L. R. (1985). Educational Evaluation and Measurement: Competencies for Analysis and Application. $2^{\text {nd }}$ Edition. Publication: C.E. Merill.

Guba, E. G., \& Stufflebeam, D. L. (1971). Evaluation: The Process of Stimulating, Aiding, and Abetting Insightful Action.

Jamal, O., \& Yaghoob, J. (2014). Selected Research Issues in the Malaysian Agricultural Sector. Journal of Malaysia Economy, 48(2), 127-136.

Ministry of Agriculture (MOA). (2012). My Kampung My Future. Content Journal. www.moa.gov.my. Uploaded on 1 October 2016.

Norhasni, Z. A., Mohd Ashraff, M. A., \& Anzar, A. (2015). Youth Involvement in Commercial Agriculture and Industrial Development in Malaysia. SIPATAHOENAN, 1(1).

Pallant, J. (2013). SPSS Survival Manual. Philadelphia: Open University Press.

Patton, M. Q. (2002). Qualitative Evaluation and Research Methods. California: Sage Publication. Beverly Hills.

Stufflebeam, D. L. (1970). Evaluation: The Process of Stimulating, Aiding and Abetting Insightful Action. Institute of Education Sciences. Ohio State of University.

Stufflebeam, D. L. (1973). An introduction to the PDK book. Educational Evaluation: Theory and practice, 128-142.

Stufflebeam, D. L., Folely, W. J., Gephart, W. J., Guba, E. G., Hammod, R. I., Merriman \& Provus. (1971). Education Evaluation and Decision-making. Itasca, IL: Peacock. 